\title{
OPTIMALIZACE MATERIÁLOVÝCH PARAMETRŮ NA ZÁKLADĚ MONITORINGU PAŽÍCÍ KONSTRUKCE
}

\author{
OPTIMIZATION OF THE MATERIAL PARAMETERS BASED ON \\ RETAINING WALL MONITORING
}

Pavel Koudela ${ }^{*}$, , Juraj Chalmovský ${ }^{1}$, Lumír Miča ${ }^{1}$

"koudela.p@fce.vutbr.cz

${ }^{1}$ Vysoké učení technické v Brně, Fakulta stavební, Veveří 331/95, 60200 Brno

\begin{abstract}
Abstrakt
Monitoring konstrukcí se obvykle využívá pro ověření chování navržené geotechnické kontrukce. Tato měření mohou být využita i jako alternativa pro stanovení materiálových parametrů s využitím optimalizační procedury, která slouží jako nástroj $\mathrm{k}$ určení vstupních parametrů materiálových modelů z výsledků inklinometrického měření pažící konstrukce. Optimalizační procedura Particle swarm optimization (PSO) pro řízení změny materiálových parametrů byla spojena se skriptovací úlohou provádějící předávání dat softwaru Plaxis založeného na MKP. Tímto postupem byly optimalizovány vstupní parametry pro Hardening soil model pro brněnský neogenní jíl. Výsledky optimalizačních procedur potvrdily, že je možné optimalizce využít jako vhodný nástroj pro stanovení parametrů zemin pro materiálové modely.
\end{abstract}

Klíčová slova

Optimalizace hejnem částic, pažící konstrukce, Hardening Soil model, materiálové modely

\begin{abstract}
Geotechnical monitoring is usually used for the verification of designed constructions. A result of the monitoring could be used as an alternative for the determination of material parameters involving optimization procedures. The optimization procedure will be used as a tool for determining material parameters using the inclinometer measurement of a retaining wall. The simple script involving data processing between Plaxis and optimization procedure Particle swarm optimization (PSO) was written. In this way, the input parameters of Brno Miocene clay for the Hardening Soil model were optimized. The results of the optimization procedures confirm the hypothesis, the optimization could be used as a useful tool for determining the material parameters of soils.
\end{abstract}

\section{Key words}

Particle swarm optimization, retaining wall, Hardening Soil model, material models

\section{1 ÚVOD}

S rozvojem numerických metod ve stavebnictví, se tento jev projevil i v geotechnickém inženýrství. S tímto, pro spolehlivou analýzu řešených konstrukcí, byla vytvořena řada materiálových modelů. Přesná predikce chování konstrukcí je závislá na správném stanovení vstupních parametrů těchto materiálových modelů. Tyto materiálové charakteristiky je možnost stanovit dvěma způsoby. Obvykle jsou to laboratorní zkoušky, kterými je možné přímo stanovit potřebné parametry. Druhou možností je využít in-situ měření, a to polní zkoušky nebo data z monitoringu konstrukcí.

V tomto článku je představena možnost využít monitoring konstrukce jako vstup pro optimalizaci parametrů materiálových modelů. Obvykle se monitoring konstrukcí využívá jako nástroj ke kontrole a ověření návrhu dané konstrukce. $\mathrm{V}$ těchto případech může také sloužit jako sledování konstrukce $\mathrm{z}$ hlediska její bezpečnosti a na základě varovných stavů určit, zda je třeba konstrukci podrobněji sledovat, zesílit, či hrozí její bezprostřední kolaps.

Deformace pažící konstrukce získané z monitoringu budou sloužit jako tzv. přesné řešení pro optimalizační algoritmus. Optimalizační algoritmus na základě těchto dat a predikovaných deformací z matematického modelu, 
bude řízeně měnit vstupní parametry pro materiálový model zemin, což má za následek změnu predikované deformace pažící konstrukce. Cílem optimalizačního algoritmu je najít takovou sadu vstupních parametrů, se kterou bude predikovaná deformace konstrukce ve shodě s přesným řešením. Matematický model pro tuto úlohu byl vytvořen v softwaru Plaxis 2D. Jako optimalizační algoritmus byl zvolen Particle swarm optimization (PSO).

V rámci tohoto článku byla vytvořena programová aplikace, která zajišt’uje předávání dat mezi softwarem Plaxis a implementuje optimalizační algoritmus PSO, který slouží k řízené změně vstupních parametrů. Cílem je ověřit, zda tato metoda získání vstupních parametrů je možná, poskytuje spolehlivé výsledky a je možné tyto výsledky získat v úměrném čase. V rámci tohoto ověření byly provedeny optimalizace za účelem získání vstupních parametrů pro Hardening soil (HS model) [1] a Hardening soil small strain model (HSS model) [2].

\section{OPTIMALIZAČNÍ ALGORITMUS}

Zvolený optimalizační algoritmus Particle swarm optimization (PSO) byl vybrán na základě jeho jednoduché implementace a dobrých výsledků rychlosti konvergence $\mathrm{k}$ minimu funkce [3]. Poprvé byla PSO představena v roce 1995, kdy tento koncept založený na pozorování hejna živočichů prezentovali Eberhart a Kennedy [4] a [5]. Algoritmus PSO se řadí do skupin metaheuristických optimalizačních algoritmů, založených na evolučním chování. Hlavním elementem, se kterým se v tom algoritmu pracuje je tzv. částice hejna. Tato částice prohledává zadaný prostor nad optimalizovanou funkcí a schraňuje nejlepší funkční hodnotu pro konkrétní částici v osobním repozitáři. Mimo to, a mimo ostatní optimalizační algoritmy, byla PSO první, kde byly všechny částice propojeny tzv. kolektivní pamětí, ve které sdílí vždy nejlepší funkční hodnotu celého hejna. Základní algoritmus PSO je potom následující:

- Náhodně rozmístit po prohledávaném prostoru částice.

- Pro všechny částice vyhodnotit hodnotu její účelové funkce.

- Pro všechny částice vyhodnotit, zda je v osobní paměti lepší funkční hodnota, pokud ne, nahrad' ji novou funkční hodnotou.

- Vyhodnot', zda kolektivní pamět' obsahuje lepší funkční hodnotu než nějaká z částic, pokud ne, nahrad' ji touto nejlepší hodnotou.

- Každé částici změň rychlost a polohu dle (1).

$$
\begin{gathered}
v_{i}^{t}=v_{i}^{t-1}+c_{1} \epsilon_{1} \odot\left(p_{i}-x_{i}^{t-1}\right)+c_{2} \epsilon_{2} \odot\left(g^{*}-x_{i}^{t-1}\right) \\
x_{i}^{t}=x_{i}^{t-1}+v_{i}^{t}
\end{gathered}
$$

,kde $v_{i}^{t}$ je nová rychlost částice, $\boldsymbol{v}_{i}^{t-1}$ je rychlost částice z minulé iterace, $c_{1} \boldsymbol{\epsilon}_{\mathbf{1}} \odot\left(\boldsymbol{p}_{i}-\boldsymbol{x}_{i}^{t-1}\right)$ je člen závislý na osobní paměti částice, $c_{2} \boldsymbol{\epsilon}_{2} \odot\left(\boldsymbol{g}^{*}-\boldsymbol{x}_{i}^{t-1}\right)$ je člen závislý na globální paměti častice, $\boldsymbol{x}_{i}^{t}$ je nová ploha částice a $\boldsymbol{x}_{i}^{t-1}$ je poloha částice $z$ minulé iterace.

- Pokud je dosaženo ukončovacího kritéria ukonči optimalizaci, pokud ne, pokračuj od druhého bodu ve stejné cyklu.

Tento algoritmus zůstal prakticky nezměněn, i přes to, že se od vzniku PSO celá řada autorů snažila algoritmus vylepšit za cenu získání rychlejší a spolehlivější konvergence [6], [7] a [8]. Změna, která se odehrávala v průběhu vývoje PSO různými autory, byla především ve změně vztahu pro výpočet nové rychlosti částice. Podrobnější popis analýzy, která varianta změny rychlosti byla vybrána pro nasazení v aktuální aplikaci, přesahuje možnosti tohoto článku. Hlavním kritériem byla však spolehlivost nalezení minima tzv. testovacích funkcí, kde byla hodnocena průměrná vzdálenost částic hejna od minima funkce po určitém počtu iterací. Výsledným vztahem (2) pro změnu rychlosti, se dle analýzy ukázala být varianta prezentovaná se zahrnutím tzv. omezujících koeficientů [8]. Tyto parametry významně ovlivňují chování optimalizačního algoritmu a přispívají k optimální rychlosti konvergence za přijatelný čas, což bylo diskutováno i v dalších pracích. Jsou to koeficienty $c_{1}$ a $c_{2}$, oba $\mathrm{s}$ hodnotou 1,49618. Hodnoty koeficientů $c_{1}$ a $c_{2}$ mají za úkol udržet roj částic $\mathrm{v}$ pohybu $\mathrm{k}$ minimu funkce a neuváznout v lokálním minimu. Tato situace může nastat, pokud je zvolena př́liš malá hodnota těchto koeficientů. Tyto koeficienty určují váhu osobní paměti a globální paměti hejna částic při výpočtu nové rychlosti částice. Ke vztahu (1) přibyl i parametr $\omega$, který je parametrem tlumení neboli faktorem, který snižuje váhu předchozí rychlosti částice. Hodnota tlumení je exponenciálně klesající s počtem iterací, kde záklaem mocniny je hodnota 0,99 , exponentem je pořadové číslo iterace. Kombinace tlumení a omezujících koeficientů vedla při analýzách k dobrým výsledkům konvergence algoritmu PSO.

$$
\begin{gathered}
\boldsymbol{v}_{\boldsymbol{i}}^{t}=\omega \boldsymbol{v}_{i}^{t-1}+c_{1} \boldsymbol{\epsilon}_{\mathbf{1}} \odot\left(\boldsymbol{p}_{i}-\boldsymbol{x}_{i}^{t-1}\right)+c_{2} \boldsymbol{\epsilon}_{\mathbf{2}} \odot\left(\mathrm{g}^{*}-\boldsymbol{x}_{i}^{t-1}\right) \\
\boldsymbol{x}_{i}^{t}=\boldsymbol{x}_{i}^{t-1}+\boldsymbol{v}_{i}^{t}
\end{gathered}
$$


Částice hejna, která je hlavní prvek v této optimalizační metodě obsahuje vektor proměnných. Tento vektor může mít libovolnou velikost a obsahuje složky souřadnic polohy částice v prohledávaném prostoru. Z polohy částice v prostoru je poté vyhodnocena tzv. účelová funkce neboli funkční hodnota optimalizované funkce, jelikož složky vektoru, kterými je částice definována jsou její proměnné. Optimalizační metoda se podle představeného algoritmu snaží dosáhnout řízenou změnou vektoru proměnných každé částice nejlepšího výsledku optimalizované funkce (nejčastěji nalézt minimální či maximální hodnotu).

\section{OPTIMALIZACE PARAMETRŮ Z MONITOROVANÉ KONSTRUKCE}

Optimalizace vstupních parametrů HS a HSS modelu byla provedena na základě dat z monitoringu reálné konstrukce. Jedná se o konstrukci pažící stěny, která byla zhotovena jako monolitická betonová podzemní stěna. Monitorovaná pažící stěna byla zhotovena pro výstavbu Technologického centra Královopolských tunelů v Brně. Hloubky lamel dosahovaly délky až $34,5 \mathrm{~m}$ a jejich tloušt'ka byla $0,8 \mathrm{~m}$. Podzemní stěna byla rozepřena v 7 úrovních vždy dvojicí válcovaných profilů. Oblast pode dnem budoucí stavební jámy byla zpevněna tryskovou injektáží a následně na dně byla vybetonovaná deska tloušt'ky $0,8 \mathrm{~m}$ [9]. Před betonáží podzemní stěny byla umístěna do prostoru výztuže plastová trubka sloužící jako vedení pro inklinometr. Inklinometrická měření byla prováděna $\mathrm{v}$ různých časových úsecích a jejich cílem bylo zaznamenat vodorovné pohyby pažící konstrukce. Z jedné etapy měření byla převzata data, která budou sloužit jako cílové hodnoty deformace pro optimalizační algoritmus.

Optimalizovaným parametrem v prezentovaných optimalizačních úlohách jsou vstupní parametry materiálových modelů. Materiálové charakteristiky ovlivňují chování zemin a jejich odezvu na různé typy zatížení. Pro konkrétní případ zmiňované pažící konstrukce materiálové parametry ovlivní zejména deformace konstrukce. Měřené deformace pažící konstrukce z monitoringu, slouží jako cíl pro optimalizační algoritmus. Shody měření a predikce z numerického modelu se bude algoritmus snažit dosáhnout řízenou změnou vstupních parametrů, kterou zajišt'uje právě optimalizační algoritmus.

\section{Geologie}

Geologie území je typická pro tuto část Brna. Kvartérní pokryvné vrstvy mají báze v hloubkách 0,6 m, 5,2 m a 9,5 m a skládají se z navážky, spraše a písčitého štěrku. I tyto vrstvy byly zahrnuty do numerického modelu sledované stavební jámy a byly modelovány Mohr-Coulombovým materiálovým modelem (MC model) viz [10]. Zbylá část konstrukce, více než 2/3, je umístěna v neogenní jílu typickým pro Brno. Pouze proto byly vstupní parametry neogenního jílu, pro HS a HSS model, vyhledávány optimalizačním algoritmem.

\section{Metodika}

Optimalizace vstupních parametrů je až posledním krokem prací, které jsou spojeny s optimalizací prováděnou v rámci tohoto článku. Samotný optimalizační algoritmus a celá aplikace pro optimalizaci by měla být autonomní bez nutnosti zásahu, mimo vyzvednutí dat a jejich analýzy. Před získáním vstupních parametrů optimalizačním algoritmem bylo nutné provést:

- Vytvoření skriptu pro tvorbu matematického modelu v programu Plaxis $2 \mathrm{D}$, včetně částí řídících změnu vstupních parametrů materiálového modelu a vyzvednutí dat po numerické analýze

- Implementaci optimalizační procedury založenou na PSO

- Spojit předchozí dvě části v aplikaci pro získání vstupních parametrů optimalizací

Prvním krokem bylo vytvoření kódu pro automatické generování matematického modelu, které je v programech Plaxis umožněno tzv. remote scripting. Tato nadstavba dovoluje uživateli napsat programový kód, v programovacím jazyce Python, a vytvářet tak automatizované procesy, které mu umožní jednoduše opakovat různé činnosti. S tímto bylo nutné aplikovat i procesy pro změnu vstupních parametrů materiálového modelu a zejména i pro vyzvednutí dat. Data potřebná pro optimalizaci jsou predikované vodorovné posuny konstrukce získané z numerické analýzy. Úrovně, ze kterých jsou predikované vodorovné deformace získávané jsou totožné jako u monitoringu konstrukce inklinometrem.

Druhým krokem bylo převedení PSO do podoby programového kódu. Vybraná podoba PSO a vztahu pro změnu rychlosti/polohy částice byla popsána v minulé kapitole. 


\section{Aplikace optimalizační metody na řešenou úlohu}

V minulé kapitole byl popsán i princip samotné optimalizace. Pro optimalizaci vstupních parametrů materiálových modelů na základě monitoringu konstrukce, je však nutné uvést některá specifika a tím popsat podrobně i metodiku optimalizace.

Zmiňovaný vektor proměnných bude v této aplikaci sloužit pro uložení vektoru optimalizovaných vstupních parametrů materiálových modelů. Druhým zmiňovaným termínem byla účelová funkce. v optimalizaci, nebo-li získání nejlepšího výsledku primitivní funkce je to prostá funkční hodnota funkce. v této aplikaci optimalizace je získání účelové funkce obtíženější, viz rovnice 3.

$$
f=\sum_{i=1}^{n}\left|u_{i, h}^{\text {meas }}-u_{i, h}^{f e m}\right|
$$

,kde $f$ je účelová funkce (mm), $u_{i, h}^{\text {meas }}$ je měřená hodnota vodorovné deformace pažící konstrukce v i-té úrovni inklinometrem $(\mathrm{mm}), u_{i, h}^{f e m}$ je predikovaná hodnota vodorovné deformace pažící konstrukce vi-té úrovni $\mathrm{z}$ numerické analýzy $(\mathrm{mm})$.

Účelová funkce $\mathrm{v}$ př́ípadě optimalizace vstupních parametrů materiálového modelu není jednoduše stanovitelná, jako např. u primitivních funkcí. Její vyhodnocení, resp. vstup $u_{i, h}^{f e m}$ je závislý na hodnotě vstupních parametrů materiálového modelu a pro jeho vyhodnocení je zapotřebí numerické analýzy.

Při analýze spolehlivosti varianty PSO, při které bylo sledováno dosažení minima testovacích funkcí, bylo vybrána kombinace počtu částic a iterací, 10 a 50. To se však ukázalo v reálné aplikaci jako nadhodnocené a při syntetickém experimentu bylo možno dosáhnout minima spolehlivě již při 5 částicích a 20 iterací, celkově tedy 100 výpočtech. Jeden běh optimalizační procedury se ukázal jako nedostatečný z hlediska možné variability získaných výsledků (viz další kapitola). Z tohoto důvodu byly provedeny tři běhy optimalizační procedury, pro stanovení možné variability výsledku.

\section{Optimalizace vstupních parametrů}

Pro optimalizaci vstupních parametrů byly vybrány dva pokročilé materiálové modely. Hardening soil model s dvojitým zpevněním a Hardening soil small strain model navíc zahrnující tuhost v malých přetvořeních. Tyto modely obsahují celou řadu vstupních parametrů. Optimalizovány však byly pouze parametry či jejich kombinace uvedené v Tab. 2 a Tab. 3.

Jako počáteční hodnoty vstupních parametrů neogenního jílu byly zvoleny parametry, které vyšly z numerické studie stejné pažící konstrukce [10] viz Tab. 1.

Tab. 1 Výchozí hodnoty vstupních parametrů materiálového modelu pro neogenní jíl.

\begin{tabular}{ccccccccc}
\hline & $\begin{array}{c}\boldsymbol{E}_{\text {ur }}^{\text {ref }} \\
(\mathbf{k P a})\end{array}$ & $\begin{array}{c}\boldsymbol{E}_{\text {oed }}^{\text {ref }} \\
(\mathbf{k P a})\end{array}$ & $\begin{array}{c}\boldsymbol{E}_{\mathbf{5 0}}^{\boldsymbol{r e f}} \\
(\mathbf{k P a})\end{array}$ & $\begin{array}{c}\boldsymbol{c}^{\prime} \\
(\mathbf{k P a})\end{array}$ & $\begin{array}{c}\boldsymbol{\varphi}^{\prime} \\
\left({ }^{\circ}\right)\end{array}$ & $\begin{array}{c}\boldsymbol{m} \\
(-)\end{array}$ & $\begin{array}{c}\boldsymbol{G}_{\mathbf{0}}^{\text {ref }} \\
(\mathbf{k P a})\end{array}$ & $\begin{array}{c}\boldsymbol{\gamma}_{\mathbf{0} .7} \\
(-)\end{array}$ \\
\hline Neogenní jíl & 36170 & 11860 & 11860 & 6 & 24 & 0,5 & 60000 & 0,0001 \\
\hline
\end{tabular}

Uvedené parametry jsou vstupní hodnoty parametrů pro HSS model, v případě HS modelu nejsou brány v úvahu veličiny $\boldsymbol{G}_{\mathbf{0}}^{r e f}$ a $\boldsymbol{\gamma}_{\mathbf{0 . 7}}$. Optimalizovány byly pro HS model parametry:

- $E_{u r}^{r e f}$

- $\quad E_{u r}^{r e f}$ a $\varphi^{\prime}$

Pro HSS model to byly parametry:

$$
\begin{array}{ll}
\text { - } & E_{u r}^{r e f} \\
\text { - } & E_{u r}^{r e f} \text { a } \varphi^{\prime} \\
\text { - } & E_{u r}^{r e f} \text { a } G_{0}^{r e f}
\end{array}
$$

V Tab. 2 a Tab. 3 jsou uvedeny optimalizované kombinace vstupních parametrů, tzn. parametry materiálového modelu, které byly optimalizačním algoritmem dohledávány. Ostatní parametry materiálového modelu, pokud nejsou zahrnuty v optimalizované kombinaci, jsou udržovány na svých výchozích hodnotách z Tab. 1 . 
Tab. 2 Hodnoty optimalizovaných parametrů pro HS model.

\begin{tabular}{cccc}
\hline Optimalizovaná kombinace & $\begin{array}{c}\boldsymbol{E}_{\boldsymbol{u r}}^{\boldsymbol{r e f}} \\
(\boldsymbol{k P a})\end{array}$ & $\begin{array}{c}\boldsymbol{\varphi}^{\prime} \\
\left.\boldsymbol{(}^{\circ}\right)\end{array}$ & $\begin{array}{c}\boldsymbol{f} \\
(\boldsymbol{m})\end{array}$ \\
\hline \multirow{2}{*}{$\boldsymbol{E}_{\boldsymbol{u r}}^{\boldsymbol{e} \boldsymbol{f}}$} & 55024 & - & 0,085 \\
& 55022 & - & 0,085 \\
\multirow{2}{*}{$\boldsymbol{r e f}$} & 55020 & - & 0,085 \\
$\boldsymbol{E}_{\boldsymbol{u r}}-\boldsymbol{\varphi}^{\prime}$ & 46610 & 27,4 & 0,080 \\
& 46862 & 27,3 & 0,080 \\
& 57703 & 23,2 & 0,087 \\
\hline
\end{tabular}

Tab. 3 Hodnoty optimalizovaných parametrů pro HSS model.

\begin{tabular}{|c|c|c|c|c|}
\hline Optimalizovaná kombinace & $\begin{array}{c}E_{u r}^{r e f} \\
(k P a)\end{array}$ & $\begin{array}{l}\varphi^{\prime} \\
\left(^{\circ}\right)\end{array}$ & $\begin{array}{c}G_{0}^{r e f} \\
(k P a)\end{array}$ & $\underset{(\boldsymbol{m})}{\boldsymbol{f}}$ \\
\hline \multirow{4}{*}{$E_{u r}^{r e f}$} & 44244 & - & - & 0,071 \\
\hline & 44220 & - & - & 0,071 \\
\hline & 44075 & - & - & 0,070 \\
\hline & 36789 & 26,2 & - & 0,068 \\
\hline \multirow[t]{3}{*}{$E_{u r}^{r e f}-\varphi^{\prime}$} & 39881 & 25,2 & - & 0,069 \\
\hline & 42700 & 24,4 & - & 0,070 \\
\hline & 33741 & - & 74761 & 0,064 \\
\hline \multirow[t]{2}{*}{$E_{u r}^{r e f}-G_{0}^{r e f}$} & 37996 & - & 70096 & 0,066 \\
\hline & 41736 & - & 64882 & 0,063 \\
\hline
\end{tabular}

V Tab. 2 a Tab. 3 jsou uvedeny optimalizované kombinace vstupních parametrů, dosažená hodnota optimalizovaného parametru a v posledním sloupci hodnota účelové funkce. Tato hodnota byla optimalizačním algoritmem minimalizována a je ukazatelem, jak blízko se nachází predikované deformace reálnému měření pažící konstrukce. Je tedy ukazatelem, který optimalizační běh dosáhl nejlepší shody s reálným měřením. V předchozí kapitole bylo zmíněno, že pro zjištění variability získaných hodnota optimalizovaných parametrů, byly provedeny tři běhy optimalizační procedury. Ty jsou v tabulkách vyjádřeny jako tři sady optimalizovaných hodnot pro jednu optimalizovanou kombinaci.

\section{DISKUZE}

Souhrn výsledků optimalizovaných parametrů je uveden v Tab. 2 a Tab. 3. Je možné si povšimnout, u HS i HSS modelu, že pokud je optimalizován pouze jeden parametr, konkrétně to bylo $\boldsymbol{E}_{u r}^{\boldsymbol{r e f}}$, optimalizační algoritmus dosáhl při všech třech opakováních stejných hodnot optimalizovaného parametru. U ostatních kombinací optimalizovaného parametru tomu tak nebylo. Dá se tedy usoudit, že optimalizační algoritmus může mít problémy při více optimalizovaných parametrech. Pokud bychom se zaměřili pouze na shodu měření a predikce, vycházející z optimalizovaných hodnot parametrů, bylo dosaženo stejné shody u všech opakování z optimalizované kombinace. $Z$ toho plyne, že různou kombinací vstupních parametrů materiálového modelu, se dá dosáhnout stejné shody s měřením. Dle definice HS modelu, to může být i tím, že celková tuhost je závislá na hodnotě úhlu vnitřního tření. V případě HSS modelu a kombinace $\boldsymbol{E}_{u \boldsymbol{r}}^{\boldsymbol{r e f}}-\boldsymbol{G}_{\mathbf{0}}^{\boldsymbol{r e f}}$ toto nejde potvrdit, tyto parametry jsou na sobě nezávislé. Pravděpodobnější se jeví to, že oba parametry výrazně ovlivňují deformace konstrukce. Parametr $\boldsymbol{E}_{u r}^{\text {ref }}$ tuhost zeminy, $\boldsymbol{\varphi}^{\prime}$ rozvoj plastických deformací, které ovlivňují opět celkové deformace konstrukce. U HSS modelu $\boldsymbol{G}_{\mathbf{0}}^{r e f}$ ovlivňuje tuhost v malých přetvořeních a zároveň velikost intervalu přetvoření, ve které se tato tuhost projevuje.

Předchozí tvrzení se dají podložit př́mo hodnotami vstupních parametrů získaných optimalizací. Pokud jeden parametr je nižší, např. tuhost, je potřeba zvýšené deformace zapříčiněné tímto parametrem zachytit zvýšením parametru úhlu vnitřního tření, aby bylo dosaženo stejné shody s měřením konstrukce. Stejně toto platí u HSS modelu, kde snížení tuhosti v oboru malých přetvoření, zapříčiní zvýšení tuhosti v odlehčení/opětovném přitížení. 


\section{ZÁVĚR}

Dle výsledků optimalizačních procedur je možné prohlásit, že optimalizace jsou dalším způsobem, jak získat materiálové parametry zemin. Výhodou může být, že pokud by optimalizační algoritmus a celá procedura byla vhodně nastavena, může být získání parametrů automatizované. Zejména by se toto dalo použít pro typické in-situ zkoušky, u kterých je výhoda, že zemina není při zkoušení porušena.

U úlohy prezentované $\mathrm{v}$ tomto článku může být dalším prvek, který významně ovlivní výsledky, kromě materiálových parametrů, i samotný numerický model, který je interpretací skutečného stavu. Jeho správné vytvoření je pro tuto úlohu zásadní.

Tato studie však nedala spolehlivou odpověd’ na spolehlivost optimalizační procedury. Dle výsledků je nutno konstatovat, že v řešené úloze se nachází několik lokálních minim, se stejnou výslednou hodnotou účelové funkce, se stejnou shodou měřených a predikovaných deformací. $\mathrm{K}$ těmto lokálním minimům však přísluší různé kombinace vstupních parametrů materiálového modelu. Řešení tedy není jednoznačné. Optimalizační algoritmus však minima dosáhl, což bylo hlavním cílem. Algoritmus toto však nemůže rozlišit bez zásahu uživatele, nebo přísnějšího omezení prohledávaného prostoru. Možným řešením tohoto problému je využití více-kriteriálního PSO, neboli Multi Objective Particle Swarm Optimization (MOPSO).

\section{Poděkování}

Tento článek a práce v něm prezentované, byly podpořeny projektem specifického výzkumu FAST-S-21-7350 Zkoumání dílčích aspektů mechanicko-teplotního chování piloty, financovaným Ministerstvem školství, mládeže a tělovýchovy České republiky.

\section{Použité zdroje}

[1] Schanz, T., Vermeer, P.A. \& Bonnier, P.G., 1999. The hardening soil model: Formulation and verification. Beyond 2000 in Computational Geotechnics, pp.281-296. Available at: https://www.taylorfrancis.com/books/9781351464307/chapters/10.1201/9781315138206-27.

[2] Benz, T., 2007. Small-strain stiffness of soils and its numerical consequences, Stuttgart: Inst. für Geotechnik.

[3] Kennedy, J., Eberhart, R.C. \& Shi, Y., 2001. Swarm intelligence, San Francisco: Morgan Kaufmann.

[4] Eberhart, R. \& Kennedy, J., 1995. A new optimizer using particle swarm theory. In MHS'95. Proceedings of the Sixth International Symposium on Micro Machine and Human Science. IEEE, pp. 39-43. Available at: http://ieeexplore.ieee.org/document/494215/.

[5] Kennedy, J. \& Eberhart, R., 1995. Particle swarm optimization. In Proceedings of ICNN'95 International Conference on Neural Networks. IEEE, pp. 1942-1948. Available at: http://ieeexplore.ieee.org/document/488968/.

[6] Shi, Y. \& Eberhart, R., 1998. A modified particle swarm optimizer. In 1998 IEEE International Conference on Evolutionary Computation Proceedings. IEEE World Congress on Computational Intelligence (Cat. No.98TH8360). IEEE, pp. 69-73. Available at: http://ieeexplore.ieee.org/document/699146/.

[7] Eberhart, R.C. \& Shi, Y., 2000. Comparing inertia weights and constriction factors in particle swarm optimization. In Proceedings of the 2000 Congress on Evolutionary Computation. CEC00 (Cat. No.00TH8512). La Jolla, CA, USA: IEEE, pp. 84-88. Available at: http://ieeexplore.ieee.org/document/870279/.

[8] Poli, R., Kennedy, J. \& Blackwell, T., 2007. Particle swarm optimization. Swarm Intelligence, 1(1), pp.33-57. Available at: http://link.springer.com/10.1007/s11721-007-0002-0 [Accessed December 28, 2017].

[9] Horák, V. ed., 2012. Královopolský tunel Brno, V Brně: Doplněk.

[10] Miča, L. et al., 2011. Numerická analýza pažení stavebních jam, Brno: Akademické nakladatelství CERM. 